\title{
Winter management practices to optimise early spring pasture production: a review
}

\author{
A.J. WALL ${ }^{1}$, D.R. STEVENS ${ }^{1}$, B.R. THOMPSON ${ }^{1}$ and C.L. GOULTER ${ }^{2}$. \\ ${ }^{1}$ AgResearch Invermay Research Centre, Puddle Alley Rd, Mosgiel. \\ ${ }^{2} 106$ Brookby $R d$, Blenheim. \\ david.stevens@agresearch.co.nz
}

\begin{abstract}
The performance of the national ewe flock has increased significantly in the past 20 years. Pasture management in winter and early spring has a large impact on the success of the subsequent seasons. Overgrazing in winter can reduce spring pasture production by up to $80 \%$. Treading and pugging damage can also decrease spring pasture production by $10 \%$ for every $10 \%$ of bare area created. Maintaining pasture cover at over $2000 \mathrm{~kg} \mathrm{DM} / \mathrm{ha}$ can improve pasture growth, and leaving a residual pasture mass of more than $1200 \mathrm{~kg}$ $\mathrm{DM} / \mathrm{ha}$ also aids in pasture production in late winter. Techniques such as feed budgeting, longer winter feeding periods ( 4 day $c f$. 1 day shifting) and increasing the control of feed intake during late pregnancy can be used to help achieve the goals of higher pasture residuals and increased pasture growth and availability. More tools for managing the transition from winter rotational grazing to spring continuous grazing would help farmers.
\end{abstract}

Keywords: early spring production, grazing management, pasture cover, residual cover, treading.

\section{Introduction}

What has changed over the past 20 years that impacts on how sheep and beef farm systems should manage pasture? Sheep and beef farm systems have come under pressure from competing land uses, mainly due to dairy expansion. Davison (2012) outlined changes in the sheep industry. Since 1994 breeding ewe numbers have gone from 34.4 million to 20.8 million in 2011. Lambing percentage has increased from 103\% in 1994 to $125 \%$ in 2011 , while lamb carcass weights have increased from $15.0 \mathrm{~kg}$ to $18.4 \mathrm{~kg}$ over the same period. That has seen lamb meat production increase from 11.5 $\mathrm{kg} / \mathrm{breeding}$ ewe in 1994 to $18.0 \mathrm{~kg} / \mathrm{breeding}$ ewe in 2011 (Davison 2012).

Many of our feeding practices are based on research from the 1960s to 1980s. New Zealand sheep research during the 1960s to 1980s reported ewe live weights of 45 to $55 \mathrm{~kg}$ (e.g., Smeaton \& Rattray 1984), while recent research (e.g., Kenyon et al. 2011) reports ewes of 60 to $70 \mathrm{~kg}$. To get a ewe to produce twins or triplets with weaning weights that may be 3 to $10 \mathrm{~kg}$ heavier
(Kenyon et al. 2011; Thompson et al. 2004) than in the 1980s (Smeaton \& Rattray 1984) requires ensuring that the feed supply in spring is adequate to meet the greater intake requirements for both maintenance and gestation.

Choices farmers make about winter pasture management have a significant impact on the early spring feed supply and pasture growth. Pasture growth in the early spring period has a large impact on a beef and sheep farming system. It influences many key activities, such as: winter stocking rates, lambing and calving dates, lambing, lactation and weaning potential, and efficiency of finishing growth rates.

Farmers need to make greater use of available pasture management tools and knowledge to effectively manage winter pastures if further productivity gains are going to be made on sheep and beef farms. Many of these tools can be used to help more effectively manage winter and early spring pastures (Webby \& Bywater 2007). These include feed budgeting, feed wedges, spring rotation planners and the concept of a balance date. Many of these tools come from the dairy industry (Holmes \& Roche 2007) and are yet to be taken up on sheep and beef farms. However, by using these pasture management tools, sheep and beef farmers have the opportunity to improve the feed supply on their farms in early spring when animal demand is at its highest, relative to new pasture growth.

Of specific importance is the role that management practices applied in the early to mid winter have on late winter and early spring feed supply and animal production. Many current farm management systems accumulate (stockpile) feed in late summer and autumn to be fed out during winter. Winter growth then accounts for much of the available feed during early spring as pasture growth starts to catch up with feed demand. Animals affect pasture production through grazing (defoliation), treading, and return of dung and urine. These effects may be more apparent during winter and early spring because pasture growth is slow and soil conditions can lead to greater treading damage.

The intent of this review is to help us better understand how winter pasture management may alter the amount of feed available in late winter and early 
spring to improve the productive performance of ewes in early lactation and for finishing cattle.

The following are a list of questions which this paper will explore to help clarify the impacts of winter pasture management on subsequent spring pasture production.

1. How much leaf should I leave behind to maximise late winter and early spring pasture growth?

2. What if I leave extra grass on the paddock in the hope that early spring growth will increase?

3. What if I keep the stock off the pasture to prevent treading and pugging?

4. How do I move from winter rotational grazing to spring set stocking?

\section{How much leaf should I leave behind to maximise late winter and early spring pasture growth?}

Leaves are essential for photosynthesis but are also the principle plant component consumed by grazing animals. Animal production from a grazing system depends on a balance between growing pasture and consuming it, aiming to optimise this throughout the year. Essential to managing the amount of leaf area left after grazing is an understanding of the development of leaves under differing light and temperature conditions.

Leaf area index (LAI) is a term used to describe the plant's surface area, and potential to capture sunlight for photosynthesis (Brougham 1958, 1960; Watson 1947). Many perennial pasture grasses achieve maximum light interception at a LAI of between 4 and 6. However, the critical LAI also varies depending on the leaf angle and the angle of incidence of sunlight (Hodgson 1990), meaning that it will be lower during winter and if pasture species have more horizontally arranged leaves (e.g. clovers).

LAI interacts with new leaf emergence, with new leaves maximising their photosynthetic efficiency by being exposed to high light intensities as they emerge (Hodgson 1990). Therefore, the new emerging leaves need to be exposed to direct sunlight early in their emergence, and maintaining a pasture's LAI at a too a high level may reduce its overall photosynthetic capacity. New leaves are also more efficient than old leaves, and so a balance in emergence and defoliation needs to be met.

LAI is a reflection of the current status of the amount of photosynthetic capability of the pasture. However, the growing units of the pasture plant, those that provide the leaf, are turning over all the time, as tillers and stolons.

If we reflect on winter conditions then we see cool temperatures and low light levels. Autumn saved pastures retain a relatively high number of leaves, as leaf death decreases at temperatures below $10^{\circ} \mathrm{C}$ (Hunt \& Field 1979), providing plenty of available pasture for grazing. However, low light levels may restrict net pasture growth and promote senescence. Generally we see that total pasture mass in winter seldom exceeds $3000-4000 \mathrm{~kg} \mathrm{DM} / \mathrm{ha}$ because of this effect.

The most important practical considerations come when grazing these pastures. Enough leaf needs to be removed to get light to the base of the pasture to help stimulate new tiller and leaf growth (Hodgson 1990), while meeting animal demand, and leaving enough leaf to maximise rapid pasture growth. If the LAI is reduced to below 4 , then pasture production is reduced. ALAI of 4 is approximately $3-4 \mathrm{~cm}$ of pasture height. However, animal demand in winter is well above pasture growth and so often winter pastures are grazed much closer to the ground than $3-4 \mathrm{~cm}$. Of critical importance to the grazing system is that the LAI of pastures is back to optimal levels in early spring as light levels and temperature increase.

New Zealand research illustrates the impacts of winter grazing height (or residual LAI) on spring production. Frequent hard grazing events at heights to less than $1 \mathrm{~cm}$ (approximately $650-800 \mathrm{~kg} \mathrm{DM} / \mathrm{ha}$ ) limited spring pasture growth onset by approximately 4 to 6 weeks and total yield by up to $50 \%$ (Harris \& Brown 1970; Black 1975).

\section{What if I leave extra grass on the paddock in the hope that early spring growth will increase?}

This question raises two separate issues. The first is the potential to increase pasture growth in the short term. The second is the impact that winter grazing may have on pasture growth and feed quality later in spring.

Recent research suggests that increasing the residual pasture cover up to approximately $2000 \mathrm{~kg} \mathrm{DM} / \mathrm{ha}$, will provide extra growth in winter (Matthew et al. 1995). Bluett et al. (1998) investigated the influence of winter pasture mass on growth on both sheep and beef and dairy farms and concluded that on dairy farms pasture production was maximised at a pasture cover of approximately $2500 \mathrm{~kg} \mathrm{DM} / \mathrm{ha}$, while the optimum cover was harder to define on a sheep and beef farm.

Lee et al. (2005) considered residual pasture covers during winter (rather than whole farm cover) and concluded that grazing to 1260 or $1870 \mathrm{~kg} \mathrm{DM} / \mathrm{ha}$ provided similar regrowth potential, though there was a small transient reduction of water soluble carbohydrates in the residual pasture at $1260 \mathrm{~kg} \mathrm{DM} / \mathrm{ha}$. This may be significant if frequent defoliation to low residuals takes place during winter, and may help explain the slow start to spring recovery measured by Harris \& Brown (1970).

Cattle grazing systems have also been compared. Boom \& Sheath (2000) used slow or fast rotations (120 cf. 45 days) during the winter in Waikato. Steers 
grew faster over the winter on the fast rotation $(24 \mathrm{~kg}$ heavier), but more feed was on offer in early spring when a slow rotation was used $(300-500 \mathrm{~kg} \mathrm{DM} / \mathrm{ha}$ more). Maintaining high pasture covers on bull beef units throughout winter in Manawatu has also been shown to have a significant positive impact on pasture growth in late winter and spring (Coutinho et al. 1998). Good feed planning which maintained pasture covers at approximately $2000 \mathrm{~kg} \mathrm{DM} / \mathrm{ha}$ produced between 800 and $1800 \mathrm{~kg} \mathrm{DM} / \mathrm{ha}$ more feed, mainly over the period of early July to mid September (Coutinho et al. 1998) and translated into increased liveweight gain in cattle at this time. Both of these examples illustrate the importance of maintaining relatively high pasture covers in winter to maximise late winter and early spring production. Importantly, the stocking rate of all systems was similar, as was per head performance. The key difference was the management input into assessing and allocating feed, with attention to using grazing cover targets.

The question of the impact of winter grazing residuals on spring feed quality has received little experimental attention and research on this topic is currently under way. Boom \& Sheath (2000) made reference to spring pasture quality, but identified the major limitation to pasture quality as high pasture growth rates in spring leading to poor late spring pasture quality, rather than a carry-over effect from ungrazed winter pasture. Smeaton \& Rattray (1984) also recognised a similar situation in sheep systems. These issues are more appropriately managed by flexible spring stocking policies, rather than winter grazing management.

Leaving a greater residual pasture mass after grazing does appear to improve both winter and spring production. Research has shown that this can be achieved within a framework of meeting animal demand (Boom \& Sheath 2000; Coutinho et al. 1998) when techniques like feed budgeting are used.

\section{What if I keep the stock off the pasture to prevent treading and pugging?}

Treading damage to pastures comes in several forms. This can be through tiller and leaf damage or compaction and pugging. Each of these has different impacts on the pasture and its future response. Tiller and leaf damage influence the utilisation of the pasture at the time of grazing, and the future production of that pasture.

Compaction and pugging affect the soil conditions and therefore influence the supply of air, water and nutrients to the roots (Drewry et al. 2008). Often significant pugging damage is more likely to occur with cattle grazing (Betteridge et al. 1999). Data from Drewry et al. (2008) and Nie et al. (2001) indicates that spring pasture production may be reduced by approximately $10 \%$ for every $10 \%$ of the paddock that is pugged, though recovery from pugging does occur, often within 3 to 6 months (Drewry 2006).

Tiller and leaf damage (Edmond 1964) and compaction (Betteridge et al. 1999) may occur with all classes of livestock, depending on soil conditions and stocking rate. Some pasture grasses are more resilient to treading than others, with perennial ryegrass being most resilient with a reduction in pasture growth of up to $23 \%$ at high sheep stocking rates, while browntop and Yorkshire fog are the least resilient with potential reduction of up to $63 \%$ at similar high sheep stocking rates (Edmond 1964). This has significance in hill country pastures where often pastures have a very high abundance of the more susceptible pasture grasses such as browntop and Yorkshire Fog (e.g., Chapman \& Clark 1984).

Macroporosity (a measure of compaction) often ranges between 5 and $20 \%$ of the soil volume. Pasture production may increase by approximately $1 \%$ for every $1 \%$ increase in macroporosity over this range (Betteridge et al. 2003).

Brown \& Harris (1972) compared two wintering systems, restricted grazing when extremely wet or full stand-off pad use throughout the winter, and found the ewe intake was higher on the restricted grazing system, though pasture cover in August was higher on a full stand-off situation.

Practically some options are available to farmers. A longer grazing duration during winter (4 days $c f .1$ day) may increase late winter and early spring pasture growth by up to $80 \%$ (Stevens et al. 2011). This was attributed to greater post-grazing pasture residuals and less tiller damage in wet conditions. Lower treading damage was noted as stocking density and walking were reduced. Again, the pasture allowance and subsequent ewe performance was similar under both 1 and 4 day grazing durations.

Farmers may reduce cattle treading damage by providing sacrifice or runoff areas during times of greatest risk, or confine cattle to feed pads during the wetter months.

\section{How do I move from winter rotational grazing to spring set stocking?}

This topic is of significant importance to sheep and beef farmers as they move into lambing and calving. This becomes a balance between current feed availability and current and future growth. Dairy farmers use a variety of pasture management tools such as spring rotation planners, balance dates and feed wedges to help with this transition. The difference between dairy and sheep and beef farmers is that dairy farmers are transitioning 
from a long rotation to a short rotation, while sheep and beef farmers are transitioning from rotational grazing to continuous grazing. This means that different tools are required to aid this transition. Surprisingly, there is little research helping define appropriate strategies to achieve this. Bircham (1984) modelled the interactions between pasture cover and pasture growth rate in spring on ewe and lamb performance to weaning. He concluded that a higher herbage mass at lambing resulted in greater weight of lamb weaned, regardless of pasture growth rate. Lower starting pasture covers depressed pasture growth more, and maximum weight of lamb was weaned at his highest opening cover of $1200 \mathrm{~kg} \mathrm{DM} / \mathrm{ha}$. This modelling was done using singlebearing ewes of approximately $50 \mathrm{~kg}$ liveweight and confirmed the conclusions of Smeaton \& Rattray (1984) that feed supply post-lambing has a significant impact on weight of lamb weaned. Ewe productivity is much greater now than in the early 1980s.

While liveweight gain of lambs from birth to weaning depends strongly on feed supply after lambing, lamb survival is affected by the dam's feed supply before lambing. Scales et al. (1986) demonstrated that increasing ewe liveweight by up to $15 \mathrm{~kg}$ in the 6 weeks before lambing increased the survival of twin born lambs by $5 \%$ per $10 \mathrm{~kg}$ gained. This effect was not significantly related to an increase in lamb birth weight, but can be explained by the work of EverettHincks et al. (2004a,b) who documented a link between maintaining ewe condition score, maternal behaviour and lamb survival. Litherland et al. (1999) investigated the impacts of ewe condition score and herbage mass at lambing on early and late lambing flocks of twinbearing ewes in the Wairarapa. They concluded that a high ewe condition score was important when weather conditions were adverse, increasing docking percentage by $17 \%$, and that high herbage mass was important for early lambing flocks, when pasture growth was unable to meet ewe demand, increasing lamb weaning liveweight by $2 \mathrm{~kg}$. This emphasises the interaction between current feed availability and pasture growth.

Maintaining the balance between improving lamb survival and maximising lamb growth after birth is important to overall production. Methods to control feed supply and demand include maintaining control of feed by break-feeding up to lambing, rather than early set-stocking, keeping ewes on crop to let pastures recover from winter grazing, and using potential individual lambing date information (gathered by the use of pregnancy scanning and ram harnesses) for accurate feed allowance. Other options such as grazing off and buying supplements are also available.

\section{Conclusion}

Winter grazing management practices have a major impact on the late winter and early spring feed supply. Previous research provides some insight into the type of grazing managements that may be applied during winter to maximise feed availability and pasture growth in late winter and early spring. Developing grazing management plans that maintain high pasture covers during winter is an option that sheep and beef farmers can use to increase the supply of pasture in late winter and early spring. Elements of the plan will need to include feed budgeting, mitigation of treading and pugging damage and a consideration of the transition from the winter rotation to spring set stocking. Research demonstrates that leaving higher pasture residual herbage mass can be achieved through using feed budgeting and techniques such as longer grazing periods (4 cf. 1 day breaks) and a stand-off (or sacrifice) area to reduce treading damage. Using potential lambing date information from pregnancy scanning or ram harnesses can also help farmers plan and control feed requirements near lambing and calving when feed supply is critical for maximising animal production. More practical tools to help manage this transition phase around lambing and calving would aid farmers decision making at this time.

\section{ACKNOWLEDGEMENTS}

Many thanks to Beef + Lamb NZ and P21 for funding this review

\section{REFERENCES}

Betteridge, K.; Mackay, A.D.; Shepherd, T.G.; Barker, D.J.; Budding, P.J.; Devantier, B.P.; Costall, D.A. 1999. Effect of cattle and sheep treading on surface configuration of a sedimentary hill soil. Australian Journal of Soil Research 37: 743-760.

Betteridge, K.; Drewry, J.J.; MacKay, A.D.; Singleton, P.L. 2003. Managing treading damage on dairy and beef farms in New Zealand. AgResearch Ltd., Hamilton, New Zealand.

Bircham, J.S. 1984. Pattern of herbage growth during lactation and level of herbage mass at lambing: their significance to animal production. Proceedings of the New Zealand Grassland Association 45: 177-183.

Black, W.J.M. 1975. Winter grazing of pasture by sheep. 1. Some effects of sheep stocking density on permanent pasture, including sward recovery, botanical composition and animal performance assessments. Irish Journal of Agricultural Research 14: 275-284.

Bluett, S.J.; Matthew, C.; Bishop-Hurley, G.J.; Haslett, S.J.; Hodgson, J. 1998. The relationship between herbage mass and pasture accumulation rate in winter. New Zealand Journal of Agricultural Research 41: 299-305. 
Boom, C.J.; Sheath, G.W. 2000. The effects of winter grazing rotation speed on the performance of beef finishing systems. Proceedings of the New Zealand Society of Animal Production 60: 139-142.

Brougham, R.W. 1958. Interception of light by the foliage of pure and mixed stands of pasture plants. Australian Journal of Agricultural Economics 9: 3952.

Brougham, R.W. 1960. The effects of frequent hard grazings at different times of the year on the productivity and species yields of grass-clover pasture. New Zealand Journal of Agricultural Research 3: 125-136.

Brown, K.R.; Harris, A.J. 1972. Wintering without crops - the problems involved. Proceedings of the New Zealand Grassland Association 34: 49-56.

Chapman, D.F.; Clark, D.A. 1984. Pasture responses to grazing management in hill country. Proceedings of the New Zealand Grassland Association 45: 168176.

Coutinho, H.B.; Matthews, P.N.P.; Morris, S.T. 1998. The effect of grazing management on pasture and animal production in late autumn to early spring period in a one year bull beef grazing system. Proceedings of the New Zealand Society of Animal Production 58: 236-238.

Davison, R. 2012. Domestic trends and measuring progress against the Red Meat Sector strategy. Presentation to the Red Meat Sector Conference 2012, Queenstown. http://www.mia.co.nz/docs/mia conference/2012/Rob\%20Davidson.pdf.

Drewry, J.J. 2006. Natural recovery of soil physical properties from treading damage of pastoral soils in New Zealand and Australia: a review. Agriculture, Ecosystems \& Environment 114: 159-169.

Drewry, J.J.; Cameron, K.C.; Buchan, G.D. 2008. Pasture yield and soil physical property responses to soil compaction from treading and grazing - a review. Australian Journal of Soil Research 46: $237-$ 256.

Edmond, D.B. 1964. Some effects of sheep treading on the growth of 10 pasture species. New Zealand Journal of Agricultural Research 7: 1-16.

Everett-Hincks, J.M.; Blair, H.T.; Stafford, K.J.; LopezVillalobos, N. 2004a. The effect of ewe nutrition on maternal behaviour score and litter survival. Proceedings of the New Zealand Society of Animal Production 64: 188-191.

Everett-Hincks, J.M.; Stafford, K.J.; Blair, H.T.; Lopez-Villalobos, N. 2004b. The effect of ewe and lamb post-parturient behaviour on lamb survival to weaning: a comparative study of Finns and Texels. Proceedings of the New Zealand Society of Animal Production 64: 223-226.
Harris, A.J.; Brown, K.R. 1970. Some effects of winter grazing management on winter and subsequent spring productivity of a ryegrass-white clover pasture. Proceedings of the New Zealand Grassland Association 32: 191-197.

Hodgson, J. 1990. Grazing management: science into practice. Longman Group UK Ltd. 203 pp.

Holmes, C.W.; Roche, J.R. 2007. Pastures and supplements in dairy production systems. In: Pasture and Supplements for grazing animals. Eds. Rattray, P.V.; Brookes, I.M.; Nicol, A.M. New Zealand Society of Animal Production Occasional Publication 14: 221-242.

Hunt, W.F.; Field, T.R.O. 1979. Growth characteristics of perennial ryegrass. Proceedings of the New Zealand Grassland Association 40: 104-113.

Lee, J.M.; Donaghy, D.J.; Roche, J.R. 2005. The effect of grazing severity during winter on herbage regrowth and quality. Proceedings of the New Zealand Grassland Association 67: 141-146.

Litherland, A.J.; Lambert, M.G.; McLaren, P.N. 1999. Effects of herbage mass and ewe condition score at lambing on lamb survival and liveweight gain. Proceedings of the New Zealand Society of Animal Production 59: 104-107.

Kenyon, P.R.; Morris, S.T.; Stafford, K.J.; West, D.M. 2011. Effect of ewe body condition and nutrition in late pregnancy on the performance of triplet-bearing ewes and their progeny. Animal Production Science 51: 557-564.

Matthew, C.; Hodgson, J.; Matthews, P.; Bluett, S. 1995. Growth of pasture - principles and their application. Dairyfarming Annual (Palmerston North) 47: 122129.

Nie, Z.N.; Ward, G.N.; Michael, A.T. 2001. Impact of pugging by dairy cows on pastures and indicators of pugging damage to pasture soil in south-western Victoria. Australian Journal of Agricultural Research 52: 37-43.

Smeaton, D.C.; Rattray P.V. 1984. Winter-spring nutrition and management effects on ewe and lamb performance. Proceedings of the New Zealand Grassland Association 45: 190-198

Scales, G.H.; Burton, R.N.; Moss, R.A. 1986. Lamb mortality, birth weight and nutrition in late pregnancy. New Zealand Journal of Agricultural Research 29: 75-82.

Stevens, D.R.; Casey, M.J.; Scandrett, J.S.; Baxter, G.S. 2011. Winter feeding - changing labour requirements and productivity. Proceedings of the New Zealand Grassland Association 73: 51-56

Thompson, B.C.; Muir, P.D.; Smith, N.B. 2004. Litter size, lamb survival, birth and twelve week weight in lambs born to cross-bred ewes. Proceedings of the New Zealand Grassland Association 66: 233-237. 
Watson, D.J. 1947. Comparative physiological studies on the growth of field crops. I. Variation in net assimilation rate and leaf area between species and varieties and within and between years. Annals of Botany 11: 47-76.
Webby, R.W.; Bywater, A.C. 2007 Principles of feed planning and management. In: Pasture and Supplements for grazing animals. Eds. Rattray, P.V.; Brookes, I.M.; Nicol, A.M. New Zealand Society of Animal Production Occasional Publication 14: 189-220. 